\section{Distribution of Pollutants from a New Paper Plant in Southern Lake Champlain, Vermont and New York}

\author{
D. L. Mason
}

Department of Natural Resources, University of Michigan

Ann Arbor, Michigan 48105, U.S.A.

\section{W. Folger}

U.S. Geological Survey, Woods Hole, Massachusetts 02543, U.S.A.

R. S. Haupt

Office of the Attorney General, State of Vermont

Montpelier, Vermont 05602, U.S.A.

\section{R. R. McGirr}

Department of Earth Sciences, Dartmouth College Hanover, New Hampshire 03755, U.S.A.

W. H. Hoyt

Department of Geology, University of Delaware

Newark, Delaware 19711, U.S.A.

ABSTRACT / From November of 1973 to May of 1974, 15 arrays of sediment traps were placed along $33 \mathrm{~km}$ of southern Lake Champlain to sample the distribution of effluent from a large paper plant located on the western shore which had commenced operation in 1971. In the arrays located near the effluent diffuser pipeline as much as $2.3 \mathrm{~cm}$ of sediment accumulated, whereas elsewhere in the lake less than $1 \mathrm{~cm}$ accumulated. In the area of accelerated accumulation, sediments contained high concentrations of several components used in or derived from paper manufacturing. Values for kaolinite, expressed as the ratio of kaolinite to chlorite, for example, were as high as 1.4 , anatase $\left(\mathrm{TiO}_{2}\right)$ concentrations were as high as $0.8 \%$, organic carbon $8.7 \%$, and phosphorus $254 \mu \mathrm{g} / \mathrm{g}$; all were more abundant than in sediments collected in traps to the south or north. In surficial bottom sediments collected near each array organic carbon and phosphorus were also higher ( $4.2 \%$ and $127 \mu \mathrm{g} / \mathrm{g}$ respectively) near the diffuser than elsewhere. Thus, the new plant after three years of production measurably affected the composition of suspended sediment and surficial bottom sediment despite the construction and use of extensive facilities to reduce the flow of pollutants to the lake.

\section{Introduction}

For more than 70 years controversy has surrounded the effects of pulp and paper mill effluents on southern Lake Champlain (Leighton 1905; Folger 1972b; Folger and Haupt 1975). A mas. sive sludge bed composed mostly of untreated debris from a paper plant formerly owned by the International Paper Company (IPC) accumulated in Ticonderoga Bay, Lake Champlain, from about 1900 to 1971 near the mouth of Ticonderoga Creek. Sludge there is now exposed at the surface in some areas that were covered by $4 \mathrm{~m}$ of water in 1874 (U.S. Coast Survey Chart 1247b). Recent studies have documented the plant's contribution to the $1 \times 10^{6} \mathrm{~m}^{3}$ deposit (Folger 1972a and b; Folger and Haupt 1975; Vermont Highway Department 1972, 1973a and b; Vermont Department of Water Resources 1972; T. W. Beak Consultants Ltd. 1973; Federal Water Pollution Control Administration [FWPCA] 1968; and Federal Water Quality Administration [FWQA] 1970).

In April of 1971 the mill on Ticonderoga Creek was closed. A larger, more modern plant was opened by IPC $5 \mathrm{~km}$ to the north on the western shore of Lake Champlain the following June. Extensive primary and secondary waste treatment facilities were constructed to process the $62,000 \mathrm{~m}^{3}$ of waste water to be discharged daily from the plant. The treatment facilities consist of a head tank, aerated bacterial digestion lagoon, primary and secondary clarifiers, and a defoamer tank. The outfall consists of $500 \mathrm{~m}$ of solid pipeline connected to 244 $m$ of diffuser pipeline that extends out from the western shore on the lake bottom.

The southern part of Lake Champlain that supplies the water and receives the effluent is narrow and shallow. Its maximum width is $1.6 \mathrm{~km}$ and water in the central channel averages about $6 \mathrm{~m}$ deep. Broad, shallow ( $2 \mathrm{~m}$ deep) shelves commonly border the narrow channel. Slow $(<20 \mathrm{~cm} / \mathrm{sec})$ northward flow is 
often altered by seiches and wind-driven currents (Mt. Pleasant 1974). The waters are well mixed by wind and waves, and clay is commonly stirred up from the shallow shelf bottom, resulting in high turbidity. Both surface and bottom water suspended matter concentrations commonly are in the range of 15 to $30 \mathrm{mg} / 1$. Secchi disk transparencies are less than $1 \mathrm{~m}$ (Hunt 1972; Folger 1974). When ice covers the lake during winter, however, turbulence is greatly reduced and concentrations of natural suspended matter apparently decline as much as an order of magnitude. Thus near the plant from about December to April, suspended solids in the effluent may account for much of the total suspended matter in the lake water that cannot be observed because of ice cover. During the remaining months suspended solids from the plant are often obscured by the natural high turbidity of the lake, so documentation of the pollutant distribution requires sampling and analysis of water and sediment.

By the time enough evidence exists to determine the amount and source of pollutants in a water body it is often too late to prevent permanent damage to some ecological systems (M. Miller, personal communication). Beak (1973a) reported that as early as 1972 water color, dissolved oxygen, phosphorus, phytoplankton, and benthic studies indicated that effiuent was lowering water quality in the area of the effluent outfall pipe. Pagel (1975) suggested that changing populations of benthic organisms observed in the area of the diffuser indicated a recent change in sedimentary and hydrologic environments.

Our purpose was to assess the extent and distribution of pollutants from the new plant. Samples were obtained from 15 arrays of sediment traps set along 33 $\mathrm{km}$ of southern Lake Champlain between Stony Point, Vermont $\left(43^{\circ} 44^{\prime} 30^{\prime \prime} \mathrm{N}, 73^{\circ} 22^{\prime} \mathrm{W}\right)$, and Crown Point, New York $\left(44^{\circ} 01^{\prime} 30^{\prime \prime} \mathrm{N}\right.$, $\left.73^{\circ} 25^{\prime} \mathrm{W}\right)$. The recovered detritus and nearby bottom sediments were analyzed for concentrations of materials used in paper manufacturing, such as kaolinite (a paper filler) ${ }^{1}$, anatase (a paper whitener), organic carbon (in part derived from wood fibers), and phosphorus (added in the treatment process). We now have sufficient evidence to determine where bottom sediments have been affected and probably will be affected most severely in the future by the effluent from the paper plant.

\section{Methods}

Between November 7 and 12, 1973, with the assistance of Vermont State Police scuba divers we placed sediment traps on the lake bottom (about $6 \mathrm{~m}$ below lake level) in the main channel at 15 locations. Each trap consisted of an aluminum base with four vertical rods (Fig. 1). Each rod supported two plastic jars ( $8 \mathrm{~cm}$ diameter and $13 \mathrm{~cm}$ deep); the jars were spaced $10 \mathrm{~cm}$ apart vertically from 20 to $90 \mathrm{~cm}$ above the lake bottom. After each trap was recovered (between May 6 and 14, 1974) a sample of the surface layer of bottom sediment was collected.

The thickness of accumulated sediment in the jars was measured in the laboratory. The less than $0.59 \mathrm{~mm}$ fraction was separated, dried, weighed, and ground in a spex mixer mill. Table 1 is an analysis of error of all tests that were made.

In the pretreatment for anatase analysis, volatile solids were measured according to American Public Health Association procedures (1971) except for these modifications: (a) platinum crucibles instead of dishes were used, (b) $1-\mathrm{g}$ samples rather than 25- to 50-g samples were heated, and (c) all samples were weighed after the first hour as well as

${ }^{1}$ Kaolinite/chlorite was found to be a sensitive indicator of plant effluent. Chlorite is a common natural constituent of lake bottom sediments but kaolinite is rare. South of the new plant is Ticonderoga Bay, the kaolinite/ chlorite values for sediments underlying a thick sludge bed were often zero and commonly low; but in the sludge bed values occasionally were infinite and commonly high. after the second hour of heating. Heating the samples at $550^{\circ} \mathrm{C}$ for two hours stabilized the residue weight and preferentially destroyed the crystallinity of kaolinite and chlorite leaving the anatase unaffected. The samples were mounted using the powder method of Gibbs $(1965,1968)$ and analyzed by $x$-ray diffraction for anatase content at $3.53 \AA$. Standards were prepared in the same manner by addition of anatase to clays that were deposited in the Champlain Valley prior to $\sim 11,000$ years ago (B. Wiley, personal communication) and are similar in texture and composition to modern Lake Champlain clay but contain little or no natural anatase. The anatase peaks averaged from five consecutive runs were compared to the standards. Total anatase is reported as the percent of dry sediment weight.

Kaolinite/chlorite values were determined by $x$-ray diffraction of treated and untreated samples. First, part of an untreated dry sample was suspended in distilled water and pipetted onto a glass slide. Forty $\mathrm{ml}$ of $4 \mathrm{~N} \mathrm{HCL}$ was added to $1 / 2 \mathrm{~g}$ of the remaining part of the sample in a 50-ml beaker; they were mixed thoroughly during sonification, and heated at $70^{\circ}$ to $80^{\circ} \mathrm{C}$ in a waterbath for 44 to 48 hours. Because of evaporation distilled water was added as necessary to maintain the normality. $\mathrm{HCL}$ was pipetted off after centrifugation and the sample was rinsed three times with distilled water. This procedure destroyed the crystallinity of chlorite, and exposed the kaolinite peak $(7,17 \AA)$ with no interference from chlorite. The treated sediment was then pipetted onto a glass slide. The $4.26 \AA$ quartz peak was used to normalize the chlorite and kaolinite peaks. Thus, a value $(C)$ for the ratio of the quartz $(4.26 \AA)$ to chlorite $(14.1 \AA)$ peak height of an untreated sample and a value $(K)$ for the ratio of the kaolinite $(7.17 \AA)$ to quartz $(4.26 \AA)$ peak height of a treated sample were calculated giving a value $(\mathrm{C} \times \mathrm{K})$ for the ratio of kaolinite/chlorite.

Readily oxidizable organic carbon was measured by a modified Walkley- 
Figure 1. Sediment traps being recovered after 6-month deployment on the bottom of southern Lake Champlain. Scuba divers removed jar covers after the array was launched and replaced them before it was recovered. The contents of jars at 40,60 , and $80 \mathrm{~cm}$ above the bottom (except when insufficient sample was recovered) were analyzed for kaolinite, anatase, organic carbon, and phosphorus content.

Black titration (Gaudette and others 1974).

$\mathrm{NaHCO}_{3}$-extractable phosphorus was measured in 1-g sediment samples shaken for 45 minutes on a rotary shaker in $100 \mathrm{ml}$ of a 0.5 molar $\mathrm{NaHCO}_{3}$ solution $(\mathrm{pH}=8.5)$ and filtered through Whatman \#41 filter paper. Carbon Black ("Darco" G-60) was added to the original solution to decolorize the filtrate. The clear filtrate was diluted to a 1 to $5 \mu \mathrm{g} \mathrm{P} / 80 \mathrm{ml}$ aliquot. After isobutyl alcohol extraction phosphorus content was determined on a Cary 15 spectrophotometer at $675 \mathrm{~m} \mu$ by the intensity of the molybdenum blue color (Wright 1959).

Olsen and others (1954) described a $\mathrm{NaHCO}_{3}$-extraction method which measures the fraction of $P$ available for plant growth in soils; he used 5-g soil

Table 1 Standard Deviations for Analyses of Components Recovered in Sediment Traps

\begin{tabular}{lrrr}
\hline Test & $N$ & $\bar{X}$ & $S$ \\
\hline Kaolinite/chlorite & 8 & 0.55 & 0.15 \\
Anatase $(\%)$ & 12 & 0.31 & 0.11 \\
Organic carbon $(\%)$ & 9 & 1.23 & 0.18 \\
Phosphorus $(\mu \mathrm{g} / \mathrm{g})$ & 6 & 210 & 25
\end{tabular}

$\mathrm{N}=$ number of repeated analyses of a sample

$\bar{X}=$ mean of values

$X=$ observed sample value

$S=$ standard deviation $=\sqrt{\Sigma\left[\left(X_{i}-\bar{X}\right)^{2}\right] /(N-1)}$

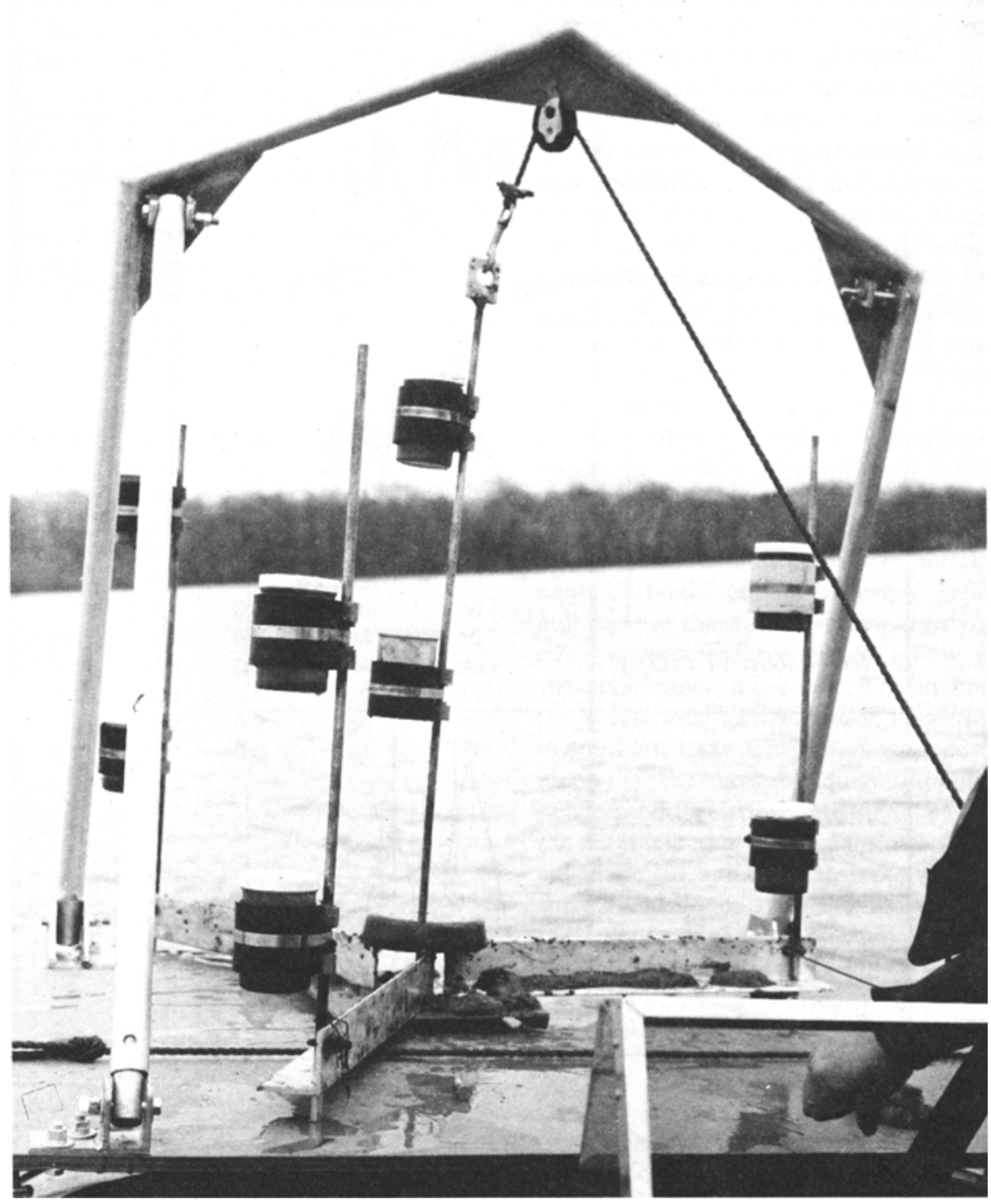

samples shaken for 30 minutes in a 0.5 molar $\mathrm{NaHCO}$ solution. Our analyses of samples run by each method indicate that Olsen's 5-g method extracts about 30 to $60 \%$ as much $P$ as the $1-\mathrm{g}$ method used in this study.

\section{Results}

As much as $2.3 \mathrm{~cm}$ of sediment accumulated during the six-month monitoring period near the new mill outfall whereas less than $1 \mathrm{~cm}$ accumulated in all other areas sampled (see Fig. 2 and Table 2). Because the traps were set just before ice formed and were removed soon after it melted, sediments collected probably contain a higher concentration of paper plant effluent than would have accumulated during other seasons when ice cover was absent and wind and waves were resuspending abundant natural sediment from the shallow shelves. 

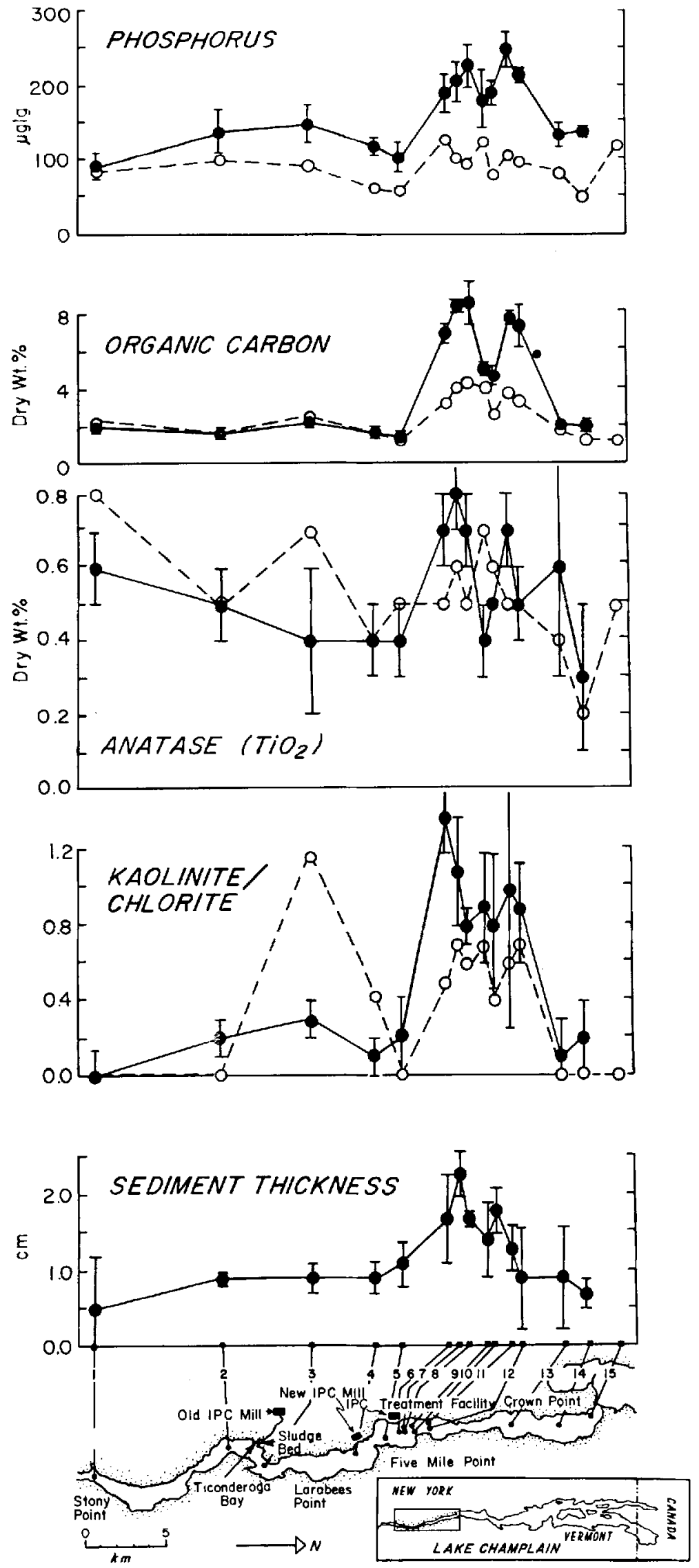

Figure 2. Average concentrations and ratios of components of sediments recovered in sediment traps (black dots) and in bottom grab samples (open circles) collected between November, 1973 and May, 1974. Vertical bars indicate standard deviation from the mean of analyses of sediments in 3 traps at each location (see Figure 3 for the location of diffuser pipeline).

Kaolinite/chlorite values in trap sediments were highest (1.4) at the new plant outfall. In surficial bottom sediments, the highest ratio (1.2) occurred in sediments collected $1 \mathrm{~km}$ north of the old sludge bed and reached 0.7 near the new plant outfall. Kaolinite/chlorite values in both trap and bottom sediments remained high about $1.5 \mathrm{~km}$ north of the new outfall. The values observed are close to or higher than those measured in bottom sediments collected near the outfall during 1972 (Fig. 3).

Anatase concentrations in trap sediments were highest $(0.8 \%)$ near the new mill outfall and remained high $6 \mathrm{~km}$ north of it. Highest concentrations in bottom sediment occurred near Stony Point $(0.8 \%)$, near the old sludge bed $(0.7 \%)$, and near the new mill outfall $(0.7 \%)$. The source of the anatase at Stony Point is not known; however, effluent from the old paper mill accounts for the abundant anatase in the sludge bed (Folger and Haupt 1975).

Organic carbon concentrations were highest in both traps $(8.7 \%)$ and bottom sediments $(4.2 \%)$ near the new mill outfall and remained high at least $1.5 \mathrm{~km}$ north of it. Natural concentrations in the channel sediments of southern Lake Champlain average only about 2 percent.

Similarly, $\mathrm{NaHCO}_{3}$-extractable phosphorus concentrations in trap sediments $(254 \mu \mathrm{g} / \mathrm{g})$ and bottom sediments (127 $\mu \mathrm{g} / \mathrm{g}$ ) were highest near the new mill outfall and remained high at least $1.5 \mathrm{~km}$ north of it. 
Table 2 Ratios and Concentrations of Components in Sediments Recovered in Sediment Trap Arrays (A) and Grab Samples (B) between November 1973 and May 1974

Values from trap samples (A) are the mean (x), and standard deviations (s) of analyses of sediment from 3 traps usually at 40,60 , and $80 \mathrm{~cm}$ above the bottom at each location (see Fig. 2). Values for grab samples are for one sample collected near each trap array.

\begin{tabular}{|c|c|c|c|c|c|c|c|c|c|c|}
\hline \multirow[t]{2}{*}{$\begin{array}{l}\text { Trap } \\
\text { array }\end{array}$} & \multicolumn{2}{|c|}{$\begin{array}{l}\text { Sediment } \\
\text { thickness } \\
(\mathrm{cm})\end{array}$} & \multicolumn{2}{|c|}{$\begin{array}{l}\text { Kaolinite/ } \\
\text { chlorite }\end{array}$} & \multicolumn{2}{|c|}{$\begin{array}{l}\text { Anatase } \\
\text { (\% dry wt.) }\end{array}$} & \multicolumn{2}{|c|}{$\begin{array}{l}\text { Organic } \\
\text { carbon } \\
\text { (\% dry wt.) }\end{array}$} & \multicolumn{2}{|c|}{$\begin{array}{l}\text { Phosphorus } \\
\text { ( } \mu \mathrm{g} / \mathrm{g} \text { dry wt.) }\end{array}$} \\
\hline & $\overline{\mathrm{x}}$ & s & $\bar{x}$ & s & $\vec{x}$ & s & $\bar{x}$ & $\mathbf{s}$ & $\bar{x}$ & s \\
\hline 1 & 0.5 & 0.7 & 0 & 0.1 & 0.6 & 0.1 & 2.0 & 0.1 & 88 & 17 \\
\hline 2 & 0.9 & 0.1 & 0.2 & 0.1 & 0.5 & 0.1 & 1.7 & 0.1 & 136 & 26 \\
\hline 3 & 0.9 & 0.2 & 0.3 & 0.1 & 0.4 & 0.2 & 2.2 & 0.3 & 149 & 29 \\
\hline 4 & 0.9 & 0.2 & 0.1 & 0.1 & 0.4 & 0.1 & 1.7 & 0.2 & 116 & 9 \\
\hline 5 & 1.1 & 0.3 & 0.2 & 0.2 & 0.4 & 0.1 & 1.5 & 0.0 & 101 & 17 \\
\hline 6 & 1.7 & 0.6 & 1.4 & 0.2 & 0.7 & 0.1 & 6.5 & 0.4 & 194 & 26 \\
\hline 7 & 2.3 & 0.3 & 1.1 & 0.3 & 0.8 & 0.1 & 8.5 & 0.1 & 210 & 28 \\
\hline 8 & 1.7 & 0.1 & 0.8 & 0.1 & 0.7 & 0.1 & 8.7 & 1.2 & 233 & 30 \\
\hline 9 & 1.4 & 0.5 & 0.9 & 0.3 & 0.4 & 0.1 & 5.1 & 0.3 & 186 & 40 \\
\hline 10 & 1.8 & 0.3 & 0.8 & 0.4 & 0.5 & 0.0 & 4.7 & 0.5 & 194 & 16 \\
\hline 11 & 1.3 & 0.3 & 1.0 & 0.8 & 0.7 & 0.1 & 7.8 & 0.3 & 254 & 25 \\
\hline 12 & 0.9 & 0.7 & 0.9 & 0.3 & 0.5 & 0.1 & 7.5 & 1.6 & 215 & 11 \\
\hline 13 & 0.9 & 0.7 & 0.1 & 0.2 & 0.6 & 0.3 & 2.0 & 0.3 & 130 & 17 \\
\hline 14 & 0.7 & 0.2 & 0.2 & 0.2 & 0.3 & 0.1 & 1.9 & 0.0 & 134 & 2 \\
\hline 15 & \multicolumn{10}{|c|}{ Not Recovered } \\
\hline
\end{tabular}

\begin{tabular}{|c|c|c|c|c|}
\hline \multicolumn{5}{|c|}{ B } \\
\hline 1 & 0 & 0.8 & 2.3 & 84 \\
\hline 2 & 0 & 0.5 & 1.7 & 100 \\
\hline 3 & 1.2 & 0.7 & 2.5 & 91 \\
\hline 4 & 0.4 & 0.4 & 1.6 & 60 \\
\hline 5 & 0 & 0.5 & 1.3 & 58 \\
\hline 6 & 0.5 & 0.5 & 3.2 & 127 \\
\hline 7 & 0.7 & 0.6 & 4.0 & 102 \\
\hline 8 & 0.6 & 0.5 & 4.2 & 96 \\
\hline 9 & 0.7 & 0.7 & 4.0 & 125 \\
\hline 10 & 0.4 & 0.6 & 2.5 & 79 \\
\hline 11 & 0.6 & 0.5 & 3.7 & 107 \\
\hline 12 & 0.7 & 0.5 & 3.2 & 96 \\
\hline 13 & 0.0 & 0.4 & 1.8 & 83 \\
\hline 14 & 0.0 & 0.2 & 1.2 & 62 \\
\hline 15 & 0.0 & 0.5 & 1.2 & 116 \\
\hline
\end{tabular}

\section{Conclusions}

In sediments collected in traps, highest values of kaolinite/chlorite, anatase, organic carbon, and phosphorus were rate (based on winter data alone) was 3.4 $\mathrm{cm}$ per year near the new mill outfall and less than $2 \mathrm{~cm}$ per year elsewhere.

In surficial bottom sediments, high kaolinite/chlorite values and anatase, organic carbon, and phosphorus concentrations were found near and at least 1.5 $\mathrm{km}$ north of the new mill outfall. However, the high kaolinite/chlorite values and anatase concentrations found $1 \mathrm{~km}$ north of the old sludge bed at Ticonderoga Bay are evidence of the long-term effect on bottom sediments of paper plant effiuent.

After three years of mill operation, sediments collected from the water column and the bottom near the new plant outfall and at least $1.5 \mathrm{~km}$ north of it contained measurable quantities of components derived from the pulp and paper mill despite the extensive treatment facility constructed to reduce inflow of such pollutants to the lake. To diminish the accelerated sedimentation occurring in southern Lake Champlain we recommend that the allowable quantity of suspended solids released into the lake from the plant be reduced by additional physical, chemical, and biological treatment of the effluent. Since 1974 the operators of the plant have investigated several methods to reduce solid outflow but no effective alteration or improvement has apparently been implemented.

\section{ACKNOWLEDGMENTS}

We wish to thank A. Johnson for advise on the analysis of phosphorus; $L$. Pool, J. Creasy, T. Ranney, and J. Hathaway for assistance in conducting analyses; the Vermont Highway Department Aerial Engineering Division, the Vermont State Police, and the Vermont Department of Water Resources for support in the collection of or analysis of samples. E. Davie and P. Forrestel kindly assisted in drafting the illustrations. Much of this study was supported financially by the Office of the Attorney General, State of Vermont. 


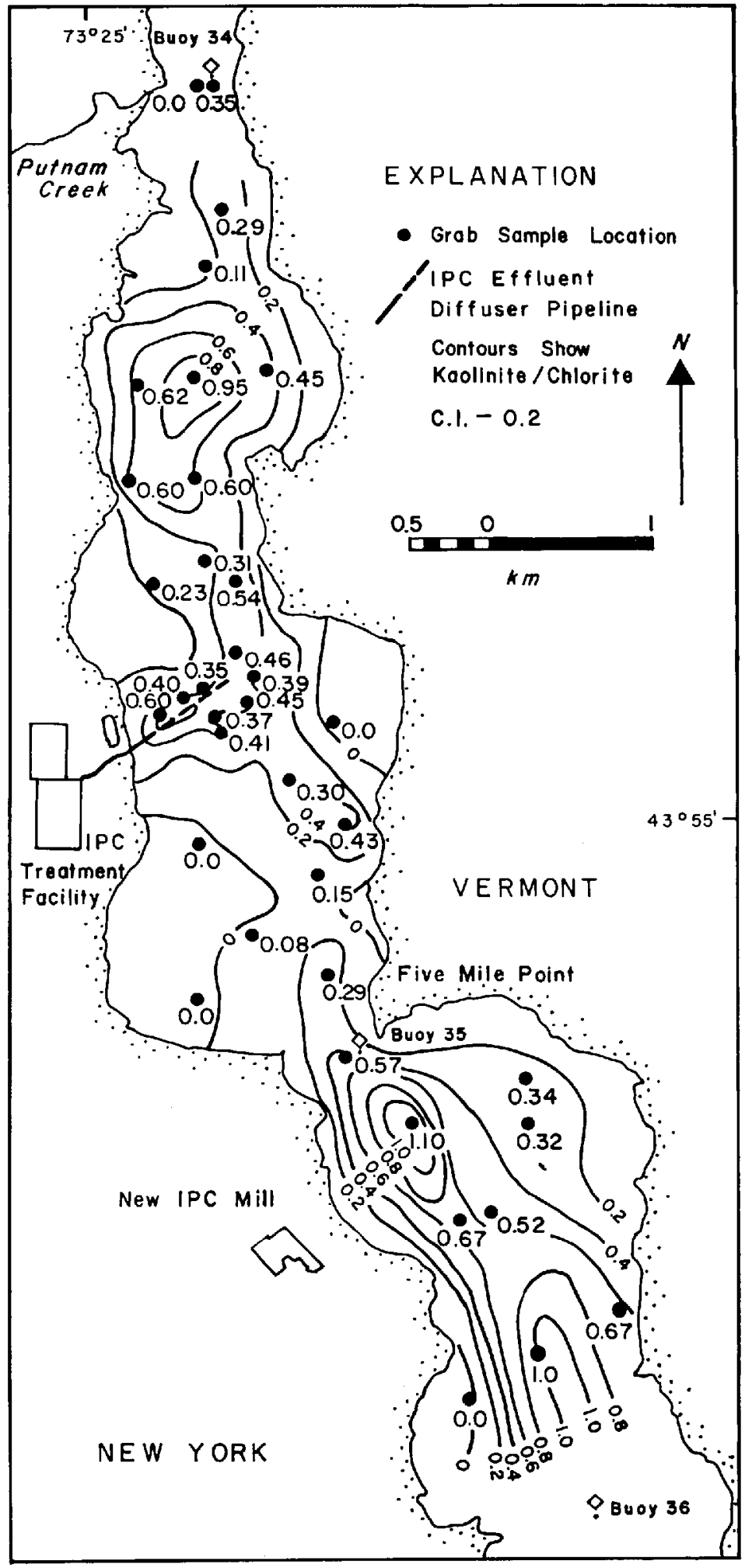

Figure 3. Kaolinite/chlorite values in grab samples collected in 1972. Contour interval is 0.2 . High values reflect addition of kaolinite from an old paper plant (see Fig. 2) and from the new IPC plant.

\section{REFERENCES}

American Public Health Association, 1971, Dissolved matter method for solid and semisolid samples, in Standard methods for the examination of water and wastewater: APHA, 13th edition, p. 539-541.

Beak, T. W., Consultants, Ltd., 1973a, Environmental impact study of pulp and paper operations at Ticonderoga, New York: Rept. for Attorney General's Office, State of Vermont, v. 1, $258 \mathrm{p}$.

1973b, Environmental impact study of pulp and paper operations at Ticonderoga, New York: Rept. for Attorney General's Office, State of Vermont, Supplemental Rept., New Mill Operations, v. 2, 165 p.

Federal Water Pollution Control Administration, 1968, Pollution of the interstate waters of Lake Champlain and its tributary basin, New York-Vermont: Proc. Conf. on Enforcement, FWPCA, 416 p.

Federal Water Quality Administration, 1970, Pollution of the interstate waters of Lake Champlain and its tributary basin, New York-Vermont: Proc. Conf. on Enforcement, FWQA, 335 p.

Folger, D. W., 1972a, Distribution of some pollutants in southern Lake Champlain, New York and Vermont (abs.): Geol. Soc. America, Prog. With Abs., v. 4, no. 1, p. 16.

1972b, The sludge bed at Ticonderoga New York, in Doolan, B. L., and R. S. Stanley, eds., New England Intercollegiate Geol. Conf. Guidebook, p. 401-406.

-1974, Water research on Lake Champlain, transcript of a conference on current knowledge, April 29, 1974: Univ Vermont, Water Research Center and Lake Champlain Committee, p. 11-12.

Folger, D. W., and R. S. Haupt, 1975, The sedimentology of Vermont vs. International Paper Company and New York State (abs.): Geol. Soc. America, Prog. with Abs. v. 7, no. 1, p. 59 
Gaudette, H. S., W. R. Flight, L. Toner, and D. W. Folger, 1974, An inexpensive titration method for the determination of organic carbon in recent sediments: Jour. Sedimentary Petrology, v. 44, p. $249-253$.

Gibbs, R. J., 1965, Error due to segregation in quantitative clay mineral $x$-ray diffraction mounting techniques: Am. Mineralogist, v. 50, p. $741-751$.

1968, Clay mineral mounting techniques for $\mathrm{x}$-ray diffraction analysis: a discussion: Jour. Sedimentary Petrology, v. 38, p. 242-244.

Hunt. A. S., E. B. Henson, and D. P. Bucke, 1972, sedimentological and limnological studies of Lake Champlain, in Doolan, B. L., and R. S. Stanley, eds., New England Intercollegiate Geol. Conf. Guidebook, p. 407-426.

Leighton, Marshall O., 1905, Preliminary report of the pollution of Lake Champlain: U.S. Geol. Survey Water Supply and Irrigation Paper No. 121, $119 \mathrm{p}$

Mt. Pleasant, Russell, 1974, Water research on Lake Champlain. transcript of a conference on current knowledge, April 29. 1974: Univ. Vermont Water Resources Research Center and Lake Champlain Committee, p. 20-27.

Olsen, Sterling R., C. V. Cole, R. S. Watanabe, and L. A. Dean, 1954, Estimation of available phosphorus in soil by extraction with sodium bicarbonate: U.S. Dept. Agriculture Circ. No. 939, 19 p.

Pagel, Carl W., 1975, A study of the influence of pulp and paper waste on the benthos of southern Lake Champlain: Burlington, Vermont, Univ. Vermont, unpub. Ph. D. dissert., 339p.

U.S. Coast Survey, 1874, Lake Champlain from Larabee Landing to Benson Landing, Chart No. 1247b (1:10,000): Hydro Data Section, National Ocean Survey-National Oceanic and Atmospheric Administration.

Vermont Department of Water Resources, 1972 , Water quality surveillance report, Lake Champlain-Ticonderoga Bay area including adjacent Vermont waters, August, 1965-November, 1972: Montpelier, Vermont, v. 1 (165 p.), v. 2 (306 p).

Vermont Highway Department, 1972, Lake bottom studies of Lake Champlain at $\mathrm{Ti}$ conderoga Creek: Montpelier, Vermont, mimeo. rept., $44 \mathrm{p}$.

-1973a, Supplemental report of lake bottom studies of Lake Champlain: Montpelier, Vermont, mimeo rept., $52 \mathrm{p}$.

-1973b, Supplemental data for lake bottom studies of Lake Champlain at Ticon- deroga Bay: Montpelier, Vermont, mimeo. rept., $46 \mathrm{p}$.

Wright, B. C., 1959, Phosphate reaction products in acid soils by the application of solubility criteria: Ithaca, N.Y., Cornell Univ., unpub. Ph. D. dissert., $201 \mathrm{p}$. 